\title{
The Urgency of Guarding Ethical Climate in Government Through Ethics Audit
}

\author{
Agus Setiawaty ${ }^{1}$, Unti Ludigdo ${ }^{2}, Z_{\text {Zaki Baridwan }}$, and Noval Adib ${ }^{4}$ \\ \{agus.setiawaty@unmul.ac.id ${ }^{1}$, untiludigdo@ub.ac.id², zaki@ub.ac.id ${ }^{3}$, noval@ub.ac.id ${ }^{4}$ \} \\ ${ }^{1}$ Mulawarman University, Samarinda, Indonesia \\ ${ }^{2,3,4}$ Brawijaya University, Malang, Indonesia
}

\begin{abstract}
The ethics of public officials is currently in the spotlight due to irregularity and violence. Issues of ethical lapse have been so turbulent and experienced astonishing trend. News about ethical infringement has been controversy in the society and significantly stimulated crisis of confidence to government. This paper aims to promote an alternative solution for government organization to improve the ethical climate that are currently being disrupted. Various efforts to guard ethics have been considerably conducted, but it seen as not sufficient enough to restore a good ethical climate in the government. Therefore, a serious effort is needed to overcome ethical issues called ethics audit. Through ethics audit, it is expected that ethical violations could be mitigated and have an impact on realization of better good government governance. Conclusion of the paper refer to the process of ethics audit model for government organization where the fraud incident and ethics violation are a real problem. Finally, it is suggested to legitimate the ethics audit as a periodic process in increasing surveillance to ethical issues in government.
\end{abstract}

Keywords: ethics, audit, government governance, fraud.

\section{INTRODUCTION}

Ethics is defined as principles that aim to evaluate right or wrong behavior, and good or bad [1]. The absence of ethics can thus be described as an action outside the limits of propriety and appropriateness in the form of violations and deviations which will ultimately have a negative impact on both individuals and the environment. One form of ethical violation which is currently in controversy especially in Indonesia is unethical actions that occur in government involving public officials. Violations against ethics among public officials have become a common view in the eyes of the public and often make headlines [2]. In Indonesia, this phenomenon is often shown through a series of arrests of public officials involved in corruption, gratuities and various other crimes. Many news proclaim about the mass corruption of council members and regional heads [3] [4], the capture of regional heads through hand-arrest operations [5] [4], and even fraud by village heads through budget abuse, illegal levies, abuse of authority, budget mark-up, fictitious reports, budget cuts and bribes [6]. The sharp focus on the ethics of public officials is 
the result of a crisis of trust in government organizations including the personnel in them. This then resulted in more serious attention to the ethics of public officials.

Various efforts to guard ethics have been considerably created in organizations both in the private sector and in the public sector. Strategies for implementing organizational ethics, which are generally carried out include creating codes of ethics [7] [8], code of conduct [8], through ethics education or training [7] [9], effective channels of communication on ethical issues, periodic inspections and punishments of ethical violators [7]. The real fact showed that those strategy is not without obstacles to be implemented. Facts on the field indicate that implementation of ethical enforcement efforts is experiencing serious obstacles. Constraints occur when there is difficulty in arousing ethical awareness of individual in the organization. The fact that organizations develop formal statements about value does not mean that the statement is really implemented [10]. Furthermore, the creation of ethics codes rarely can reduce ethical dilemmas in organizations [9]. The existence of code of ethics is not able to be a guide for organizations and personnel to behave ethically so that the code of ethics is only a symbol of sweetening organizational documents [11]. The impact is the organizations that have a written code of conduct actually do more wrong things. Meanwhile, in other studies it found that ethics as a reflection of morality, in reality, experienced developments caused by the social structure that surrounded it [12].

The inadequacy of the ethics implementation strategy that has been attempted by the organization encourage the discourse for a new system to complement the ethical enforcement process. Alternative efforts are needed if the organization is serious about doing everything possible to ensure the ethical behavior of each individual. Data from corruption index in Indonesia which only experienced a 5-point increase from 2012 as many as 32 points and in 2017 to 37 points showed a not too significant increase in the span of 5 years. This indicates the need for a stronger effort in the prevention and eradication of corruption in Indonesia [13]. Therefore, in line with what was conveyed by experts, then for countries that have serious problems with ethics it requires a far more serious effort to handle them. Such serious efforts are ethics audit [9][14][15]. An ethics audit is expected to complement the ethical enforcement process in the organization. This is because the enforcement of ethics in organizations not only guarantees an adequate ethical climate but also has the potential to mitigate opportunities for fraud.

Ethics audit is important to be implemented in government because moral, identity and capacity in decision making of a public official are confined to ethics [16]. Some literature suggests that the ethical dilemmas often encountered in public sector organizations are due to concerns over the effects of economic, managerial and privatization rationalism which lead to the emergence of questions about public goods and so-called public interests [17]. Other things that also contribute to increasing the level of ethical dilemmas for public officials are the arbitrariness of the appointment of senior public officials and the politicization of public services [18]. Allegations of the politicization of public services bring all things related to ethics and ethical behavior in the spotlight because public officials are required to be independent in carrying out their duties and obligations without getting intervention from any party. Political factors also explain the ethical climate discomfort in public sector organizations. It was stated that funding and public budgets were under pressure due to the political environment so that it had a negative impact on the ethical climate. 


\section{METHOD}

This paper attempts to identify effective means for the government in its efforts to manage ethical issues that occur. Therefore, this study uses systematic literature review to achieve the intended purpose. Systematic literature review is a research method for identifying, examining and interpreting all relevant research results on certain topics or phenomenon [19]. There are several common arguments for conducting systematic review which consists of summarizing research evidence related to particular treatment or method, identifying research gaps to find the suggestion of future investigation and providing adequate frameworks or backgrounds for further study. The systematic review generally aims to present a comprehensive overview of the literature on several topics that reach the establishment [20][21]. Through this method, research will be directed at activities to identify and evaluate the research findings particular to the implementation of ethics audits that have been carried out in several organizations and how the opportunities to be applied in government organizations. Basic principles in conducting systematic review including specify research question, conduct the literature search, determine selection and assessment method, undertake data extraction, monitoring and synthesis [22].

\section{RESULT AND DISCUSSION}

\subsection{The Meaning of Ethics Audit}

Ethics audit is a systematic approach, which provides a description, analysis and evaluation of relevant aspects of corporate ethics. The function of ethics audit is to identify the existence of ethics gaps. This gap occurs when there is a difference between the moral situation expected and real event [23]. Ethics auditing acts as a management tool that can be used to help diagnose the measurement and development of ethical content from an organization. Another derivative objective is to assist organizations in providing quick responses to issues related to conflict or potential threats arising from conflicts between stakeholders so that it is expected to minimize negative impacts for all stakeholders.

Another understanding that was attempted to describe ethics audit emerged in the $2000 \mathrm{~s}$ which view ethics audit as programs that had long-term goals for the organization. Ethics auditing means more than improving social performance, more than just "toys" of stakeholders but a systematic effort that is appropriate for describing, analyzing and evaluating aspects of behavior within the organization because it aims to maintain competitive advantage and the sustainability of the company. Ethics audit meant a regular, complete and documented measure of the suitability of declared policies and procedures. Audit of ethics can identify factors or pressures that encourage unethical behavior or that might act as incentives for unethical behavior in an organization. Ethics audit are designed to help administrators and managers of institutions, individual practitioners, supervisors, and social work educators, to consider ethical risks that can cause future problems [24]. Another concept regarding other ethics audit that emerged in the 2000s also showed that the presence of ethics audit appeared to complement the quality assurance process, and was a useful guiding tool for improving ethical risk management in institutions that had not developed policies and good procedure. Not only as an ethical risk management tool in organizations, ethics audit serves as an integrated tool to evaluate the ethical climate within the company and the sustainability of the company. Reporting produced through ethics audit is an effort to raise awareness of the company to increase the trust of all stakeholders [25].

The importance of ethics audit presented in organizations is also related with compliance value [26]. The values contained in the code of ethics are not merely created but efforts need to be made to ensure their implementation goes as expected. Aside from being a form of 
strengthening compliance with ethics, ethical auditing is needed as a step to develop and maintain an ethical corporate culture. An audit was needed to improve and improve the moral climate of the company other than merely creating a code of ethics [27]. Ethics is proposed ethics audit as a crucial step to create an ethical company so that it can be concluded that evaluation of ethical values in a company organization is a necessity to create a company that has a competitive advantage.

\subsection{Ethics Audit Position among other Preceding Audits}

The presence of ethics audit in an effort to mitigate the occurrence of fraud especially in government organizations encourages the presence of questions about the position and status of the ethical audit itself. The emergence of an ethical audit causes little doubt about its function which is considered to overlap with other audits that are present. The audit is divided into three types when viewed from its objectives, namely audit of financial statements, operational audits and compliance audits[28]. The first audit is audit of financial statements, which is an examination carried out with the aim to determine whether the financial statements are in accordance with certain criteria, in this case namely generally accepted accounting principles. The output generated from this audit is an opinion that states the reasonableness of the suitability of financial statements against the standard. This type of audit is carried out by an independent auditor appointed by the company. The second is in operational sphere. Operational audit is an examination of the operational activities of the company (organization) with the aim of evaluating the efficiency and effectiveness of each operational procedure and method. The final result of this audit is the recommendations given to improve operational activities in the future. An operational audit is also called a performance audit or management audit and is carried out by an internal audit. The last is compliance audit which define as an examination that aims to determine whether the company (organization) has complied with applicable laws and regulations. The regulations referred to are sourced from within the organization as well as the rules set by the related external parties.

In addition to the type of audit described earlier, in its development there are other types of audits that appear due to the organizational context and the interests of the relevant stakeholders. The interest is related with the purpose to increase transparency and credibility of the commitment of the company (organization) to the social (environmental) and ethical aspects [29] [30][31]. The ultimate goal is to increase stakeholders' trust in the company [32]. The audit are social audit and ethics audit. Social audit, namely the process of evaluating and reporting on the company's environmental and social performance carried out by involving stakeholders through dialogue, helping to build trust, identifying commitments and promoting cooperation between stakeholders and companies [33]. Some of the objectives of the social audit conducted are to determine the extent to which the company's social goals have been achieved, analyze and compare the social consequences of the company's activities, and the latest is to measure the company's social contribution to society using cost-benefit analysis [23]. Meanwhile, ethics audit, with its practical definition, is to evaluate the suitability between the values declared through the formal system and the actual behavior that occurs [10] [34]. Ethics audit is a systematic approach in order to build evaluation, analysis and description of the ethical aspects relevant to the organization. Ethical audit is an evaluation of the climate and environment of the organization and the implementation of ethical policies

Of the five types of audits outlined above, social and ethics audit are related to compliance audits. The compliance, social and ethics audit is related each other and ethics audit has broader scope rather than other audit [25]. The relationship between the three audits is shown through the following illustration [25]: 


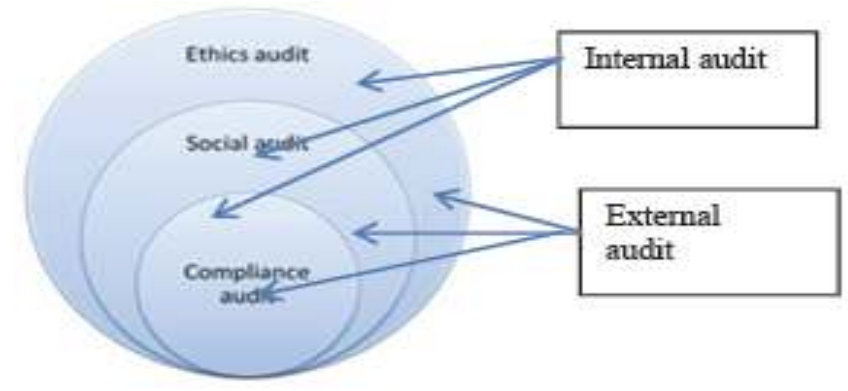

Fig 1. Relationship between compliance audit, social audit and ethics audit

The figure shows that the ethics audit is more than a compliance audit because it includes the compliance audit itself and a social audit. Compliance audits only compare internal and external regulation with internal behavior without contributing to real ethical behavior [25]. The uniqueness of ethics audit lies in different procedures and ways of achieving their goals of maintaining an ethical climate and finding ethical risks that might occur. All those audit could be performed both internal and external audit.

\subsection{The Process of Ethics Audit in an Effort to Safeguard Ethics}

Ethics audit is viewed as a way for companies to build moral trust in the stakeholder's perspectives [23]. Regarding its function, the metaphor "ethics thermometer" is given to ethics audit to explain the important function of ethics audit to measure the health condition of organizational ethics. This thermometer can later be used by company management to periodically monitor the ethical performance of each department. Furthermore, the thermometer provides specific information for managing ethics from the ground up. The results of the theoretical and empirical research found an ethical audit process included six key elements [23], including; (1) Qualities monitor; is an instrument for assessing the quality of ethics (including clarity, consistency, support, visibility) to indicate how the organization stimulates and directs ethical actions, (2) The measures scan; to investigate initiatives, activities, instruments and established rules for maintaining and improving the ethical climate in the organization, and to identify vulnerable areas where inadequate size creates opportunities for unethical actions, (3) The individual characteristics and circumstances assessment; to map the moral and environmental characteristics of individuals that can influence the likelihood of personnel engaging in unethical actions, (4) The dilemmas decoder; to oversee a comprehensive figure of conflict between the personnel interests, (5) The conduct detector; the method used to reveal the occurrence of factual unethical actions of personnel and the organization as a whole, (6) The stakeholder detector; to assess stakeholder interests and expectations and the extent to which the organization meets these expectations. The model proposed above can be a starting point for opening the way for the formation of audit models in government organizations with some characteristic adjustments to the nature of government organizations.

Whereas in its implementation in the field, ethics audit involve several audit procedures such as distributing questionnaires, interviews, group discussions and inspection of documents [30] 
[35] [36]. From all the important procedures, it is expected that identification of ethical issues and ethical problem can be carried out and can build an ethical work environment as well as the right ethical culture that can be developed in the organizational environment. It is important to note that the ethics audit model developed in government organizations should contain adequate ways to evaluate current practices, problems and potential [37]. Another important criterion is that the model built is practical and can solve ethical problems. With this criterion, it is hoped that ethics audit is not only guarding ethical issues in the organization but also serve as diagnostic tools that are able to signal fraud.

\section{CONCLUSION}

The phenomenon of ethical lapse involving public officials and the ineffectiveness of ethical systems in government organizations requires the presence of new ways to maintain the continuity of a good ethical climate. Ethics audit is the effective solution to solve ethical problems. Ethics audit is present in order to build a strong mechanism that is expected to oversee the suitability of the value structure (which describes the expectations of the institution) and the reality of ethical practices that occur in the government.

The ethics audit process itself in its implementation will really need support from all organizational elements to be able to proceed effectively. This is because the audit procedure includes several ways, including: dissemination of questionnaires, interviews, document inspections and group discussions. In order to be more effective and provide a direct impact on government organizations, it is deemed necessary to legitimize ethics audits as annual audits as other preceding audits. Thus, regulations of ethics audit should be made on periodic reporting by government organizations that assess the ethical climate in their respective institutions. To strengthen support for the role of ethical auditing, it is recommended that further research can evaluate the effectiveness of ethics audit through the processes and procedures described in this article.

\section{REFERENCE}

[1] I. Amundsen and P. Andrade, V, "Public sector ethics," Luanda and Bergen, 2009.

[2] L. C. Ehrich, N. Cranston, and M. Kimber, "Public sector managers and ethical dilemmas," J. Manag. Organ., vol. 10, no. 1, pp. 25-37, 2004.

[3] Kompas, "Kasus korupsi massal di DPRD Kota Malang, ini sejumlah faktanya," Sep2018.

[4] Detik, "Perjalanan kasus korupsi 41 anggota DPRD Malang hingga PAW masal," Sep2018.

[5] Kompas, "Hingga September 2017, 5 kepala daerah terjaring OTT KPK, siapa saja mereka?," Sep-2017.

[6] Detik, "Menyelamatkan (dana) desa," 2019.

[7] J. Greenberg, "Who stole the money, and when ? Individual and situational determinants of employee theft," Organ. Behav. Hum. Decis. Process, vol. 89, pp. 985-1003, 2002.

[8] J. F. Dillard and K. J. Yuthas, "Ethics in Action : An application of structuration theory in professional service firms," Bus. Adm. Fac. Publ. Present., 2013.

[9] L. P. White and L. W. Lam, "A proposed infrastructural model for the establishment of organizational ethical systems," J. Bus. Ethics, vol. 28, no. 1, pp. 35-42, 2000.

[10] M. Rihma and M. Meel, "The discrepancy between declared values and real ethical behavior of companies (Estonian Case)," Eur. Sci. J., vol. 9, no. 16, pp. 26-42, 2013.

[11] M. S. Schwartz, “A code of ethics for corporate code of ethics," J. Busines Ethics, vol. 41, 
pp. 27-43, 2002.

[12] U. Ludigdo, Paradoks etika akuntan. Yogyakarta: Pustaka Pelajar, 2007.

[13] TransparansiInternasional, "Layanan publik membaik, namun korupsi politik masih tinggi," 2017.

[14] D. D. DuFrene, "The external ethics audit: A guided experience in self-directed web inquiry," Teach. Bus. Ethics, vol. 5, no. 1, p. 71, 2001.

[15] Z. Rezaee, "Restoring public trust in the accounting profession by developing anti-fraud education, programs, and auditing," Manag. Audit. J., vol. 19, no. 1, pp. 134-148, 2004.

[16] C. W. Lewis and S. C. Gilman, The ethics challenge in public service, Second. San Fransisco: Jossey-Bass, A Wiley Imprint, 2005.

[17] M. Kimber and G. Maddox, "Australian public service under the Keating Government: A case of weakened accountability?," Int. J. Public Sect. Manag., vol. 16, no. 1, pp. 61-74, 2003.

[18] N. M. Ashkanasy, S. Falkus, and V. J. Callan, "Predictors of ethical code use and ethical tolerance in the public sector," J. Bus. Ethics, vol. 25, no. 3, pp. 237-253, 2000.

[19] B. Kitchenham and S. Charters, "Procedures for performing systematic literature reviews in software engineering," 2004.

[20] C. Kohtala, "Addressing sustainability in research on distributed production: An integrated literature review," J. Clean. Prod., vol. 106, pp. 654-668, 2015.

[21] R. Whittemore and K. Knafl, "The integrative review: Updated methodology," J. Adv. Nurs., vol. 52, no. 2, pp. 546-553, 2005.

[22] Y. Yuan and R. H. Hunt, "Systematic reviews: The good, the bad, and the ugly," Am. J. Gastroenterol., vol. 104, no. 5, pp. 1086-1092, 2009.

[23] M. Kaptein, Ethics management: Auditing and developing the ethical content of organization, Ten. Springer Science and Business Media Dordrecht, 1998.

[24] F. Reamer, T. Social, W. Ethics, R. M. Tool, and P. Example, "Conducting an ethics audit at your nonprofit," 2011.

[25] M. Rihma, Ethics audit a management tool for assessing of corporate social responsibility and preventing ethical risk. 2014.

[26] L. J. Brooks and P. Dunn, Business \& profesional ethics for directors, executives \& accountants, Sixth. USA: South-Western Cengage Learning, 2012.

[27] J. W. Weiss, Business ethics. South-Western Cengage Learning, 2009.

[28] A. A. Arens, R. J. Elder, and Mark S Beasley, Auditing and assurance service. PrenticeHall, 2012.

[29] R. Morimoto, J. Ash, and C. Hope, "Corporate social responsibility audit: From theory to practice," J. Bus. Ethics, vol. 62, no. 4, pp. 315-325, 2005.

[30] M. Rihma, B. Lorenz, M. Meel, and A. Leppiman, "Implementing ethics auditing model: New approach,” Sci. Pap. J. Knowl. Manag. Econ. Inf. Technol., vol. 1, no. 4, pp. 1-19, 2014.

[31] A. CARAS (FRUNZA), "Perspectives for reconstruction of ethical expertise," Postmod. Openings, vol. 5, no. 2, pp. 81-96, 2015.

[32] P. Kok, T. Van Der Wiele, R. Mckenna, and A. Brown, "Corporate social responsibility within a quality management framework," J. Bus., vol. 31, no. 4, pp. 285-297, 2010.

[33] S. S. Gao and J. J. Zhang, "Stakeholder engagement, social auditing and corporate sustainability," Bus. Process Manag. J., vol. 12, no. 6, pp. 722-740, 2006.

[34] M. Ojasoo, "CSR reporting, stakeholder engagement and preventing hypocrisy through ethics audit," J. Glob. Entrep. Res., vol. 6, no. 1, 2016.

[35] M. Ojasoo and A. Leppiman, "Ethics audit as a marketing instrument and its potential for 
organic farming," Agron. Res., 2016.

[36] D. García-Marzá, "Trust and dialogue: Theoretical approaches to ethics auditing," J. Bus. Ethics, vol. 57, no. 3, pp. 209-219, 2005.

[37] C. W. Lewis, “An agency ethics audit," Int. J. Public Adm., vol. 15, no. 8, pp. 1619-1632, 1992. 